\title{
PEMANFAATAN LAHAN PEKARANGAN DENGAN PENANAMAN ALPUKAT DAN PEPAYA CALIFORNIA UNTUK PENINGKATAN GIZI MASYARAKAT DI DESA TERONG KABUPATEN BANTUL
}

\section{HOMEGARDEN USAGE WITH AVOCADO AND CALIFORNIA PAPAYA PLANTATION TO INCREASE COMMUNITY NUTRITION IN TERONG VILLAGE BANTUL REGENCY}

Zuhud Rozaki $^{1}{ }^{*}$, Arie Kusuma Paksi ${ }^{2)}$

${ }^{1)}$ Fakultas Pertanian, Universitas Muhammadiyah Yogyakarta email: zaki@umy.ac.id

${ }^{2)}$ Fakultas Ilmu Sosial dan Ilmu Politik, Universitas Muhammadiyah Yogyakarta email: ariekusumapaksi@umy.ac.id

\begin{abstract}
ABSTRAK
Desa Terong memiliki cukup banyak kasus stunting. Perhatian terhadap pemenuhan pangan yang bergizi perlu dilakukan. Upaya peningkatan gizi masyarakat lewat pemanfaatan lahan pekarangan dengan penanaman tanaman buah seperti papaya California dan alpukat yang bergizi bisa menjadi solusi yang tepat. Kegiatan pengabdian ini bertujuan untuk meningkatkan gizi dan ekonomi masyarakat sasaran dengan memanfaatkan lahan pekarangan. Metode yang digunakan adalah penyuluhan dan pendampingan. Masyarakat sasaran sangat antusias dengan kegiatan pengabdian ini, terlihat dari jumlah peserta saat penyuluhan dan penyerahan bibit pepaya california dan alpukat. Meskipun hasil dari tanaman buah tersebut membutuhkan waktu, masyarakat sasaran merasa bahwa upaya ini cukup membantu dalam usaha perbaikan gizi masyarakat. Bahkan masyarakat berpikiran bahwa penanaman tanaman buah di lahan pekarangan ini bisa menjadi potensi pengembangan desa menjadi desa wisata berbasis buah. Jangka panjang dari dampak kegiatan pengabdian ini sangat berarti mulai dari level keluarga sampai wilayah desa. Pemenuhan gizi keluarga secara mandiri lewat lahan pekarangan perlu dikembangkan, masyarakat perlu lebih disadarkan. Selain memberikan asupan gizi yang baik, juga bernilai ekonomis.
\end{abstract}

Kata kunci: Lahan Pekarangan, Pepaya California, Alpukat, Gizi Masyarakat, Stunting

\section{ABSTRACT}

Stunting cases in Terong Village are quite high. Attention on the nutrient food fulfillment need to be more serious. Efforts to increase people nutrition through homegarden utilization with planting california papaya and avocado can be solution here. This community service activity aims to increase people nutrition and economic through homegarden utilization. Method which was used is extension and assistance. The targeted community was very enthusiastic about this community service program, it can be seen from the number of participants during extension and handing over California papaya and avocado seeds. Although the results of the fruit crops need time, the targeted community feels that this effort is quite helpful to improve people nutrition. The targeted community thinks that planting fruit trees on homegarden can be a potential for village development to become a fruit-based tourism village. The long-term impact of these community service activities is significant from the family level to the village area. Fulfillment of family nutrition independently through the homegarden utilization, the community needs to be more aware. In addition to providing good nutrition, it is also economically valuable.

Keywords: Homegarden, California Papaya, Avocado, Community Nutrition, Stunting 


\section{PENDAHULUAN}

Pangan menjadi isu strategis di negara berkembangan seperti Indonesia [1]. Kerawaran pangan yang berujung pada kurang gizi terjadi di berbagai daerah di Indonesia [2]. Banyak yang beranggapan bahwa tercukupinya karbohidrat seperti beras saja sudah cukup, padahal komponen kecukupan gizi juga sangat penting. Ada dua kemungkinan munculnya kasus kurang gizi, pertama karena kurangnya pengetahuan akan asupan gizi yang baik, kedua karena faktor ekonomi. [3] Mengatakan bahwa indikator ketahanan pangan yang ideal harus memperhatikan konsumsi kalori, kemiskinan, dan diversifikasi makanan. [4] menyampaikan bahwa dampak kekurangan makanan paling besar dirasakan oleh orang miskin, wanita dan anak-anak.

Kabupaten Bantul merupakan wilayah yang cukup berkembang di Daerah Istimewa Yogyakarta (DIY), terutama bidang pariwisata. Perkembangan sektor ekonomi ini masih memiliki pekerjaan rumah terkait kondisi kekurangan gizi. Angka prevalensi balita gizi buruk di Kabupaten Bantul dari tahun 2014 sampai tahun 2018 menunjukkan kenaikan, hal ini perlu menjadi perhatian [5]. Dampak dari gizi buruk bisa menyebabkan balita menjadi stunting. Angka stunting di Kabupaten Bantul di tahun 2019 sebesar $8,33 \%$ dari total 57.606 bayi [6].

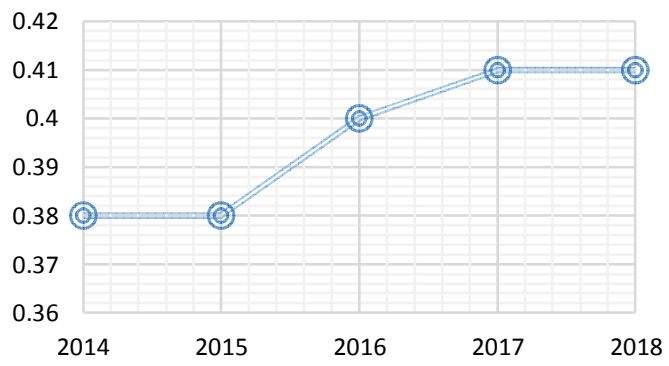

Gambar 1. Angka Gizi Buruk Balita di Kabupaten Bantul [5]

Desa terong adalah wilayah yang memiliki kasus stunting atau gizi buruk cukup banyak di Kabupaten Bantul. Pada tahun 2019, terdapat sekitar 40 anak mengalami stunting di desa ini. Berdasarkan hasil observasi lapang, keluarga yang memiliki kasus anak stunting tersebut adalah keluarga yang kurang mampu. Secara umum, untuk anak stunting yang sudah diatas 2 tahun akan sudah disembuhkan, akan tetapi untuk anak dibawah 2 tahun dan juga untuk ibu hamil bisa dilakukan antisipasi stunting dengan peningkatan gizi mereka [7].

Desa Terong terletak di daerah perbukitan, dan masyarakatnya memiliki tanah pekarangan yang cukup luas. Banyak lahan pekarangan yang belum termanfaatkan di desa ini. Pemanfaatan lahan pekarangan untuk konsumsi sendiri bagi masyarakat umum sebenanya memiliki potensi yang tinggi. Ketika tanaman yang ditanam adalah tanaman buah yang bergizi, ini bisa menjadi upaya peningkatan gizi keluarga [8]. Selain mampu menjadi sumber gizi keluarga, pemanfaatan lahan pekarangan akan mampu menopang ekonomi keluarga dengan menjual hasilnya. [9] menunjukkan bahwa 
pengembangan pertanian itu berperan Setelah dilakukan observasi lapang, Setelah penting dalam pengembangan wilayah.

dilakukan observasi lapang, dari sembilan

Pepaya California dan Alpukat adalah dusun, dipilih dua dusun yaitu Dusun tanaman yang cocok dibudidayakan di lahan Pancuran dan Dusun Terong I sebagai lokasi pekarangan yang terdapat di Desa Terong, kegiatan pengabdian. Pada kegiatan Selain cocok ditanam, kedua tanaman ini pengabdian ini dibagikan bibit papaya memiliki kandungan gizi yang banyak. california sebanyak 140 batang di Desa Manfaat dari buah papaya antara lain: Pancuran dan bibit alpukat sebanyak 100 menyehatkan mata, menyehatkan rambut dan batang di Desa Terong I.

kuku, menyembuhkan kulit yang terbakar sinar matahari, memperlancar pencernaan, kesehatan jantung, mengurangi risiko kanker, antipenuaan, meningkatkan sistem kekebalan tubuh, dan baik untuk penyakit demam dengue [10]. Sedangkan manfaat buah alpukat antara lain: protein, lemak bermanfaat, karotenoid, lutein, vitamin dan mineral, anti inflamasi, dan natrium (sodium) dan kolesterol [11].

Papaya selain dikonsumsi dalam bentuk buah potong juga bisa diolah menjadi berbagai makanan olahan yang mampu meningkatkan niali jual dari papaya itu sendiri [12]. Tidak kalah dari buah papaya, buah alpukat juga memiliki nilai ekonomis yang tinggi, dan tanpa diolahpun nilainya sudah tinggi [13]. Kegiatan pengabdian kepada masyarakat ini bertujuan untuk meningkatkan gizi dan ekonomi masyarakat sasaran dengan memanfaatkan lahan pekarangan.

METODE PELAKSANAAN KEGIATAN

Sasaran dari kegiatan pengabdian ini adalah masyarakat di Desa Terong, Kecamatan Dlingo, Kabupaten Bantul.
Ada beberapa metode yang dilakukan secara berkesinambungan untuk mencapai target kegiatan pengabdian ini, yaitu:

\section{FGD dan Diskusi}

Kegiatan ini dilakukan dengan mengumpulkan khalayak sasaran strategis untuk mengikuti Focus Group Discussion (FGD) dan diskusi tentang pengembangan menggali permasalah dan tantangan pengembangan lahan pekarangan lewat penanaman papaya california dan alpukat.

\section{Penyuluhan dan Pendampingan}

Penyuluhan dilakukan dengan materi pentingnya pemenuhan gizi keluarga untuk mengantisipasi munculnya gizi buruk dana tau stunting. Selanjutnya juga disampaikan materi tentang tentang pemanfaatan lahan pekarangan di sekitar rumah, agar lahan yang biasanya tidak dimanfaatkan bisa dimanfaatkan dengan baik, baik untuk konsumsi sendiri atau dijual untuk meningkatkan ekonomi keluarga. Pada materi ini, dimasukkan materi tentang manfaat buah papaya california dan alpukat.

Kegiatan pendampingan ini dilakukan secara periodik untuk membina dan 
mendampingi khalayak sasaran strategis sampai berhasil minimal menanam bibit yang diberikan.

\section{Monitoring dan Evaluasi Kegiatan}

Monitoring dan evaluasi ini dilakukan baik sebelum, ketika dan sesudah pelaksanaan setiap agenda pengabdian. Hal ini dilakukan untuk menjadi bahan perbaikan di masa yang akan datang.

\section{HASIL DAN PEMBAHASAN}

\section{Kondisi Umum}

Desa Terong, Kecamatan Dlingo, Kabupaten Bantul merupakah daerah dengan wilayah didominasi oleh perbukitan. Desa ini ini terdiri dari 9 dusun, yaitu: Dusun Kebokuning, Dusun Saradan, Dusun Pancuran, Dusun Rejosari, Dusun Terong Dusun Terong II, Dusun Pancitrejo, Dusun Sendang Sari, dan Dusun Ngenep. Memiliki tujuh administrasi padukuhan, dan jumlah penduduk sebesar 6.041 jiwa [14]. Kondisi jumlah penduduk dan wilayah yang cukup luas, membuat desa ini menghadapi tantangan dalam pemerataan pembangunan. Meskipun masih tergolong sebagai wilayah pedesaan, desa ini memiliki masalah kasus stunting (gizi buruk parah). Tingkat pendidikan atau kemiskinan menjadi pemicu dari masalah ini.

\section{Penyuluhan}

Penyuluhan dilakukan dua kali yaitu di Dusun Pancuran dan Dusun Terong Penyuluhan pertama dilakukan di Dusun Pancuran pada tanggal 12 Januari 2020 dari pukul 19:00 sampai 22:00 WIB.
Materi yang disampaikan pada penyuluhan ini ada dua, yaitu tentang potensi pemanfaatan lahan pekarangan untuk tanaman buah yang bisa bernilai gizi untuk keluarga dan bernilai ekonomis. Pada umumnya masyarakat sasaran tidak terlalu memperhatikan pemanfaatan lahan pekarangan, mereka lebih focus pada penanaman di kebun, berupa pohon kakao. Padahal lahan pekarangan yang mereka miliki rata-rata cukup luas. Jika lahan pekarangan tersebut bisa dimanfaatkan, keuntungannya bisa berlipat, yaitu bisa untuk konsumsi keluarga sendiri, dan bisa dijual dan menambah penghasilan.

Materi selanjutnya terkait dengan manfaat papaya california bagi tubuh dan bagaimana menanam bibit papaya ini. Secara umum masyarakat sasaran memang sudah terbiasa memakan pepaya kareana buah ini tergolong buah yang murah, akan tetapi mereka belum terbiasa memakan pepaya california. Kandungan pada pepaya ini banyak mengandung vitamin dan protein seperti vitamin $A$, vitamin $b$ dan vitamin $C$, yang bermanfaat untuk tubuh manusia. Materi tentang bagaimana menanam bibit pepaya ini juga disampaikan, mengingat bahwa masyarakat sasaran belum terbiasa dalam penanaman bibit pepaya. Secara umum cara penanamannya seperti bibit I. tanaman lain, yang perlu diperhatikan adalah sebelum bibit dimasukkan kelubang tanam, harus diberi pupuk dahulu. Kemudian dilakukan penyiraman secara rutin [15]. 


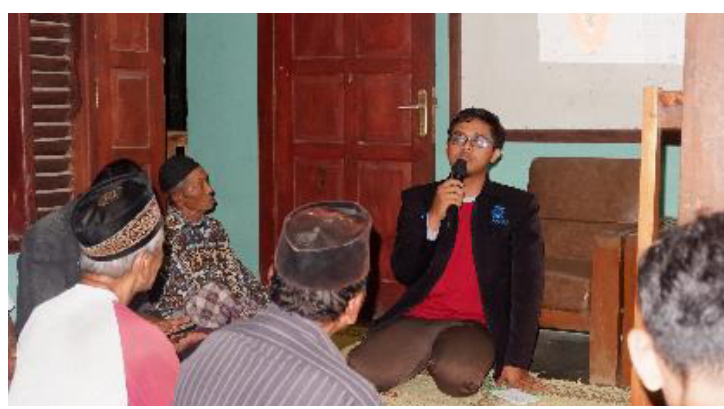

Gambar 2. Penyuluhan di Dusun Pancuran

Penyuluhan kedua dilaksanakan di

Dusun Terong I pada tanggal 16 Januari 2020 dari pukul 19:00 sampai 22:00 WIB. Pada kesempatan ini disampaikan materi tentang pemanfaatan lahan pekarang untuk ditanami tanaman buah yang bisa bernilai gizi dan ekonomis, tepatnya alpukat. Masyarakat sasaran disampaikan tentang lahan pekarangan yang punya potensi. Buah alpukat di pasaran memiliki harga yang cukup tinggi, bila masyarakat sasaran mampu mengembangkan buah alpukat ini lewat lahan pekarangan mereka, upaya peningkatan ekonomi keluarga juga bisa dicapai bersamaan dengan peningkatan gizi keluarga.

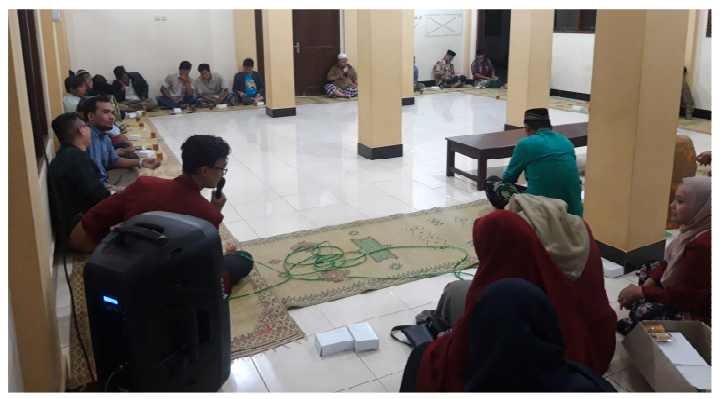

Gambar 3. Penyuluhan di Dusun Terong I

\section{Pembagian Bibit}

Pembagian bibit secara simbolik dilakukan bersamaan saat penyuluhan, sedangkan pembagian bibit lainnya dibagikan terpisah secara berkala setelah penyuluhan.

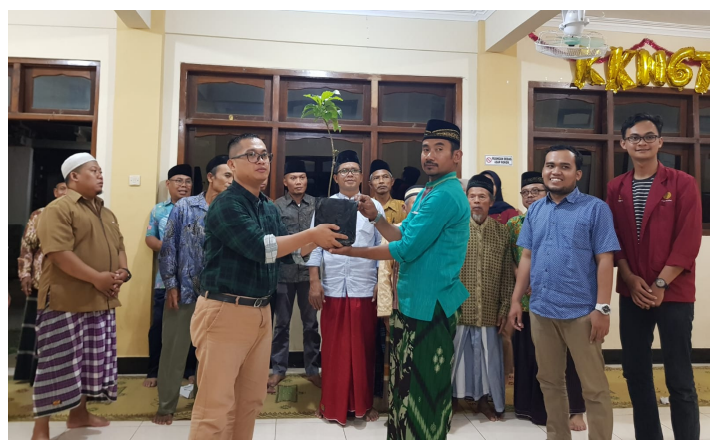

Gambar 4. Penyerahan Bibit Alpukat di Dusun Terong I

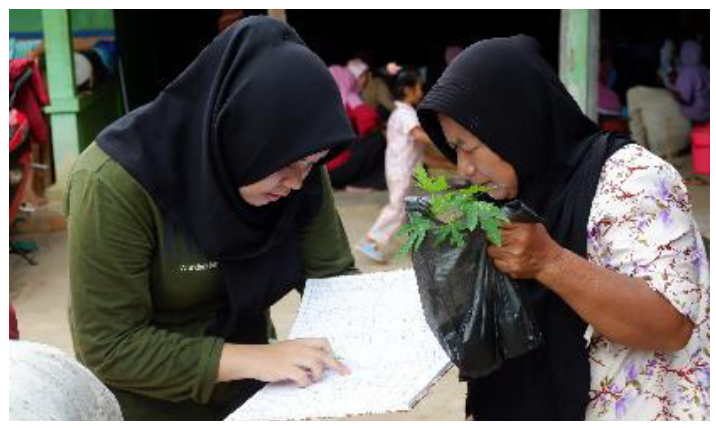

Gambar 5. Penyerahan Bibit Pepaya California di Dusun Pancuran

\section{Pendampingan}

Kegiatan ini dilakukan agar program pengabdian ini bisa berjalan dengan lancar sesuai target diawal. Terutama terkait dengan pananam bibit, agar masyarakat sasaran bisa menanam dengan tepat dan berhasil. Pendampingan dilakukan di kedua dusun yaitu Dusun Pancuran untuk penanaman bibit pepaya california dan Dusun Terong I untuk penanaman alpukat.

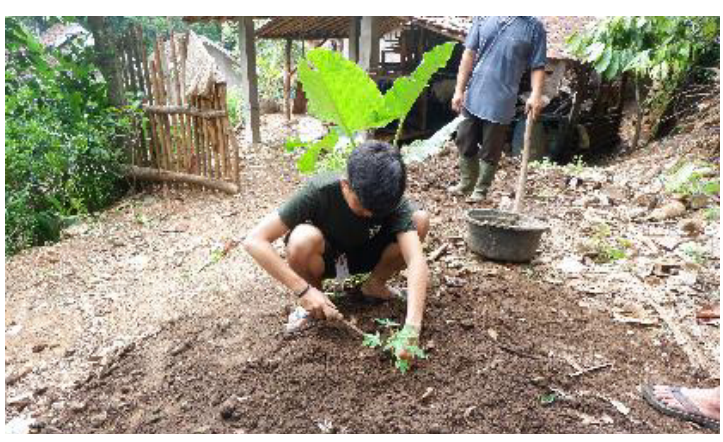

Gambar 6. Pendampingan Penanaman Bibit Pepaya California 


\section{Monitoring dan Evaluasi}

Masyarakat sasaran terlihat antusias dengan kegiatan pengabdian ini, terlihat dari dalam mengikuti rangkaian kegiatan jumlah peserta saat penyuluhan dan pengabdian ini. Saat penyuluhan ada penyerahan bibit pepaya california dan beberapa yang hadir bertanya terkair alpukat. Meskipun hasil dari tanaman buah program ini. Bahkan ada beberapa pihak tersebut membutuhkan waktu, masyarakat yang menganggab bahwa program kegiatan sasaran merasa bahwa upaya ini cukup ini bisa dikembangkan lebih jauh lain, membantu dalam usaha perbaikan gizi seperti membuat desa wisata berbasih buah.

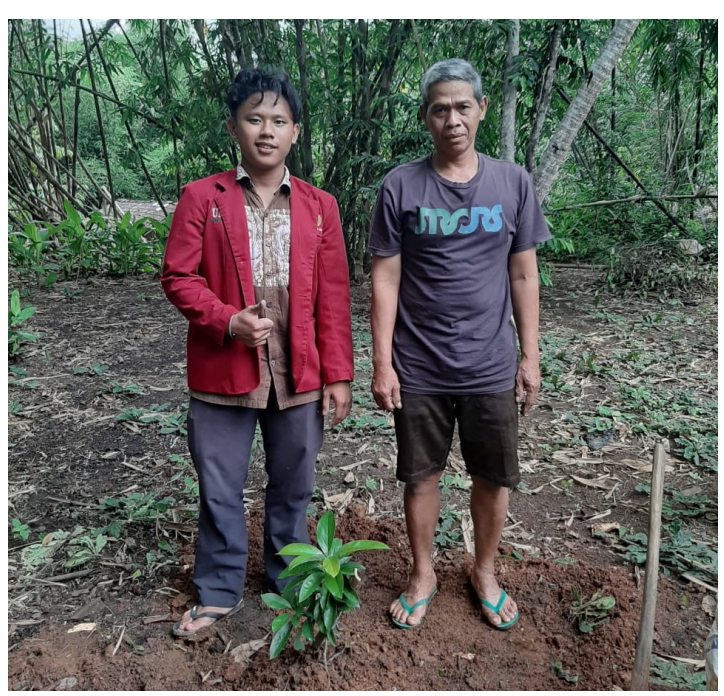

Gambar 7. Pendampingan Penanaman Bibit Alpukat

Bibit yang sudah dibagikan kepada masyarakat sasaran langsung ditanam, dan mereka berharap bisa manuai hasil yang maksimal baik untuk konsumsi sendiri ataupun dijual.

\section{KESIMPULAN}

Desa Terong memiliki cukup banyak kasus stunting. Perhatian terhadap pemenuhan pangan yang bergizi perlu dilakukan. Upaya peningkatan gizi masyarakat lewat pemanfaatan lahan pekarangan dengan penanaman tanaman buah yang bergizi bisa menjadi solusi yang tepat. masyarakat. Bahkan masyarakat berpikiran bahwa penanaman tanaman buah di lahan pekarangan ini bisa menjadi potensi pengembangan desa menjadi desa wisata berbasis buah. Jangka panjang dari dampak kegiatan pengabdian ini sangat berarti mulai dari level keluarga sampai wilayah desa.

\section{SARAN}

Pemenuhan gizi keluarga secara mandiri lewat lahan pekarangan perlu dikembangkan, masyarakat perlu lebih disadarkan. Selain memberikan asupan gizi yang baik, juga bernilai ekonomis.

\section{UCAPAN TERIMAKASIH}

Kami mengucapkan terimakasih kepada seluruh masyarakat Desa Terong, Kecamatan Dlingo, Kabupaten Bantul atas partisipasi dan kerjasamanya. Terimakasih juga kepada Kelompok KKN 079 dan 120 Periode Gasal 2020 Universitas Muhammadiyah Yogyakarta atas semua dukungan dan kerjasamanya. Serta, kami sangat berterimakasih kepada LP3M Universitas Muhammadiyah Yogyakarta atas hibah dana pengabdian Skema PKM. 


\section{REFERENSI}

[1] Wijaya O (2017). Strategi Pengembangan Komoditas Pangan Unggulan dalam Menunjang Ketahanan Pangan Wilayah (Studi Kasus di Kabupaten Batang, Propinsi Jawa Tengah). Agrar J Agribus Rural Dev Res. 3(1):48-56.

[2] Slamet Widodo A, Wulandari R (2016). Analisis Pola Konsumsi dan Tingkat Kerawanan Pangan Petani Lahan Kering di Kabupaten Gunungkidul (Studi Kasus di Desa Giritirto, Kecamatan Purwosari, Gunungkidul). Agrar J Agribus Rural Dev Res. (18):161-7.

[3] Headey D, Ecker O (2013). Rethinking the measurement of food security: From first principles to best practice. Food Secur. 5(3):327-43.

[4] Douglas I (2009). Climate change, flooding and food security in south Asia. Food Secur. 1(2):127-36.

[5] Dinas Kesehatan Kabupaten Bantul (2019). Narasi Profil Kesehatan Kabupaten Bantul 2019. 2019. Available from: https://dinkes.bantulkab.go.id/filestora ge/dokumen/2019/05/Narasi Profil Kesehatan 2019.pdf

[6] LANTIVA MC (2020). Pajangan Tertinggi Angka Kasus Stunting. Radar Jogja. Available from: https://radarjogja.jawapos.com/2020/0 1/17/pajangan-tertinggi-angka-kasusstunting/

[ 7 ] Muhdar M, Rosmiati R, Tedy Tulak G, Saputri E, Wahyu Susanti R (2019). Peningkatan Pengetahuan Tentang Pencegahan Stunting Pada Wanita Usia Subur, Ibu Hamil Dan Ibu Balita Di Kecamatan Polinggona. LOGISTA - J Ilm Pengabdi Kpd Masy. 3(2):142.

[ 8 ] Abdoellah OS, Schneider M, Nugraha LM, Suparman Y, Voletta CT, Withaningsih S, et al. (2020). Homegarden commercialization: extent, household characteristics, and effect on food security and food sovereignty in Rural Indonesia. Sustain Sci. 15(3):797-815. Available from: https://doi.org/10.1007/s11625020-00788-9

[9] Rozaki Z (2020). Carrying Capacity of Agriculture Sector Based on Commodities' Production in Kulonprogo Regency. 2020.

[ 10 ] Adrian K (2018). Manfaat Pepaya Bagi Kesehatan. Alo Dokter. 2018 [diakses pada 2020 Jun 18]. Available from: https://www.alodokter.com/manfaatpepaya-bagi-kesehatan

[11] Fadli R. 7 Nutrisi Hebat Alpukat untuk Kesehatan [Internet]. [diakses pada 2020 Jun 28]. Available from: https://www.halodoc.com/7kandungan-nutrisi-alpukat-danmanfaatnya

[ 12 ] Suyanti, Setyadjit, Arif A Bin (2012). Produk Diversifikasi Olahan Untuk Meningkatkan Nilai Tambah Dan Mendukung Pengembangan Buah Pepaya (Carica Papaya L) Di Indonesia. Bul Teknol Pasca Panen. $8(2)$.

[ 13 ] Tamalia DI, Santoso SI, Budiraharjo K (2018). Analisis Tingkat Pendapatan Usahatani Alpukat di Kelompok Tani Kabupaten Semarang. J Ilmu-ilmu Pertan. 14(1):1-11.

[ 14 ] Badan Pusat Statistik Kabupaten Bantul (2019). Kecamatan Dlingo dalam Angka 2019. 2019. Available from:

https://bantulkab.bps.go.id/publication /2019/09/26/0e548ceaf86d80348a5a1 16c/kecamatan-dlingo-dalam-angka2019.html

[ 15 ] Ismawati U. Pepaya California [Internet]. Dinas Pangan, Pertanian dan Perikanan. [diakses pada 2020 Jun 29]. Available from: https://pertanian.pontianakkota.go.id/p roduk-unggulan-detil/5-pepayacalifornia.html 